\title{
QUANTIFYING FAMILY BUSINESS OWNERS' ATTITUDES TOWARDS SUCCESSION: DELVING DEEPER BY RANDOM FORESTS
}

Kılıç, A., Filizöz, B.

Arzu Kilic / Department of Business Administration, Faculty of Economics and Administrative Sciences, Ardahan University, Ardahan,Turkey.Email: arzukilic@ardahan.edu.tr.

Berrin Filizöz / Department of Business Administration, Faculty of Economics and Administrative Sciences, Cumhuriyet University, Sivas, Turkey.Email: berrinfilizoz@gmail.com.

\begin{abstract}
Family businesses are the lifeblood of the economic growth of the nations. However, a large gap exists about the application of machine-learning algorithms such as Random Forests (RF) to the quantification of patterns, drivers, and interactions in the succession process of family businesses. The primary aim and novelty of this study lie in the quantification of variable importance based on machine-learning algorithms, and the differences among the characteristics of family businesses, family employees, and family business owners (FBOs) for multivariate responses. For this reason, a field study was carried out in family businesses in Sivas and Ardahan provinces. The questionnaire form created by the researchers was used in this study. In this research, RF classification model was applied. RF classification models of 17 response variables were constructed as a function of 32 predictors.

Implications for Central European audience: Impacts of characteristics of FBOs, family businesses, and family employees on FBOs' willingness to transfer to successors and preferences about the successor's qualities were modelled. High-dimensional data were collected from 53 family business owners (FBOs) in two cities for a total of 49 variables. As a result, the domain of the FBOs' characteristics was found to have a more profound impact on both FBO's willingness to transfer to a successor and what successor's qualities were most valued than did the domains of the family business and employee characteristics.
\end{abstract}

Keywords: machine learning; small-sized enterprises; family business

JEL Classification: M10, M59

\section{Introduction}

Family businesses, in particular, small-scale family enterprises are the backbone of national economies. Micro-scale (local) socio-economic decisions are the drivers of macro-scale (national and regional) socio-economic changes (Van Praag et al., 2007). Globally, family businesses were on average estimated to constitute $70-$ to- $90 \%$ of all business entities and create 60 -to- $90 \%$ of gross domestic product (GDP) annually (Allio, 
2004; Blodgett et al., 2011; Tucker, 2011). In Turkey, 95\% of all businesses are family businesses with a mean survival rate of 25 years 30, 12 and $3 \%$ of which have been transferred to the second, third and fourth generations, respectively (Tuncel, 2011; ASSBA, 2016). The succession process is one of the main driving forces behind the sustainability of the family business. The lack of strategical planning and management in the succession process hinders the long-term existence of family businesses (Venter et al., 2005).

Many factors influential on the successful transition of management and ownership to heirs or successors in family businesses have been studied extensively in related literature (Le Breton-Miller et al., 2004). In the literature of family business, succession has become one of the most significant themes (De Massis et al., 2008; Nordqvist \& Melin, 2010; Sharma, 2004). Chua et al. (2003) pointed out that the sustenance and transition of family business were what the family business leaders were most concerned with. The reason for this relates not only to the necessity for every family firm to be eventually transferred to an heir, or a successor as an integral part of its life cycle but also to the challenges of the complex process of "emotional and financial adaptation and management and/or ownership transfer" for family firms (Laakkonen \& Kansikas, 2011, pp. 984).

The most influential factors on the succession process were reported as the owners' attitudes towards losing their authority, control over their successors and individuality identified with firms, their senses of potential conflicts with their successors, their fear of death, and their indecision about the choice of successors (Hacıbayramoğlu, 2014). The succession as a delicate process that requires special attention is usually characterized by uncertainty, tense mood, conflict, and reorientation. For example, new roles, and their restructuring are needed to be defined for all the stakeholders involved, such as family members, transferees, potential heirs, and non-family managers and employees. Once a successor is chosen and operationally active, the power structure needs to be restructured due to its change (Zehe, 2016). The success of the succession primarily depends on successors' characteristics and attitudes, in particular, on their commitment and willingness (Chrisman et al., 1998; Sharma \& Irving, 2005). Also, heirs' or successors' related education and training, on- and off-job experience and duration, entrance level, internal position, breadth of knowledge, communication ability, trustworthiness and age also play an essential role in the selection (Hacıbayramoğlu, 2014; Kılıç \& Filizöz, 2019).

There exist various studies about the transfer of management and its management, heir or successor selection, and most sought heir or successor characteristics in related literature such as Cesaroni \& Sentuti (2017), Chua et al. (1999), Devany (2006), Gomba \& Kele (2016), Güller (2010), and Sharma \& Rao (2000). An extensive literature review (e.g., Yu et al., 2012; Bau et al., 2013) indicated that the majority of the related studies had used questionnaire data, convenience sampling, small sample sizes, conceptual analyses and descriptions, and qualitative data analyses. In addition to the above common features, interactions among multiple factors, non-linear relationships, nonparametric nature of variables measured, high-dimensional data, a large number of missing values, and the presence of outliers and noise have been an integral part of such studies and research data (Grimmer, 2015). All these challenges may render machine- 
learning algorithms useful in accounting for the drivers and patterns of the succession process since machine learning is resistant to these challenges (Lazer et al., 2009). Machine learning can be described as the process of deriving decision rules from training by examples of known input-output behaviours and their application to the problems of prediction, classification, optimization, change detection, and pattern recognition (Jordan \& Mitchell, 2015).

The primary aim and novelty of this study lie in the quantification of variable importance based on machine-learning algorithms, and the differences among the characteristics of family businesses, family employees, and family business owners (FBOs) for multivariate responses. To the best of our knowledge, there exists no study about the application of machine-learning approaches to the questionnaire data about FBOs' attitudes towards his/her heirs and successors. In particular, Random Forests (RF) is among the best of today's most powerful machine-learning methods and has not been implemented in this field thus far. To contribute to filling this gap in related literature, the objectives of this exploratory study were to (1) quantify the relative importance and sensitivity of explanatory variables in elucidating FBOs' attitudes in succession by using RF classification models; and (2) explore the benefits of adopting RF in the computational social studies.

\section{Data and methodology}

In the structured questionnaire surveys, 28 firms from the Ardahan city, and 25 firms from the Sivas city participated. The main fractions of the participants from both cities were as follows: $5.7 \%$ women, $35.9 \%$ in the age of $41-50,45.2 \%$ in the age of $\geq 51,37.7 \%$ high school graduates, $76 \%$ in favour of transferring to heir/successor, $55 \%$ those who did not determine the transfer time, and $40.8 \%$ those who planned on transferring within 1-10 years. In response to the questions about FBOs' attitudes in the process of succession preferred on-site training, monitoring, supervision, transfer of rights before and after death, and actively working after the transfer, respectively (Table A1). The participants were asked to reveal their preferences for the dichotomous questions about the successor qualities sought (as indicated by QMS in Table A1). Their most frequent responses were thus: preferred honesty, commitment to a family business, entrepreneurship, and ability to solve problems (Kılıç \& Filizöz, 2019).

A total of 17 response variables concerning FBOs' attitudes in succession and a total of 32 predictors ( 9 business characteristics +8 family employee characteristics +15 FBO characteristics) were measured on the nominal and ordinal scales (Table A1). The ordinal scale used was binary with the codes 1 and 2 referring to the least and most preferred, respectively. Quality control and quality assurance (QCQA) of the gathered data were implemented by employing the procedures of identifying erroneous values and data gaps, statistical distributions, descriptive statistics, and multicollinearity. Following the QCQA procedure, the resultant data matrix of 49 columns (variables) $\times 53$ rows $(N=$ sample size) was analyzed. Anderson-Darling (AD) statistic was performed to test the normality assumption of error terms and how well the data follow any of 14 parametric distributions and 2 transformations. The non-parametric tests of Spearman's rank-order and Kendall Tau-b rank-order correlation matrices were used to capture the strength (the magnitude of correlation coefficient $-r$ ) and direction (the sign of $r$ ) of pairwise linear relationships 
among the variables.

Since the response variables were categorical with binary values, RF classification model, a non-parametric method, was performed. The RF algorithm developed by Breiman (2001) creates an ensemble of decision trees, instead of one tree (model), based on a bootstrapping-based sampling of $N$ rows of the original data with replacement. About onethird $(37 \%)$ of the original data not included in the training dataset of a given decision tree is referred to as out-of-bag (OOB) observations and treated as a validation dataset (Breiman, 2001). The bootstrapping procedure is what most makes RF distinct and among the best of today's available machine-learning algorithms with the strongest predictive and classification power and accuracy (Luo et al., 2004). The number of decision trees to be grown was tried using 200, 500 and 1000 trees in the exploratory data analysis and was determined finally as 200 . The number of predictors tested at each node in RF was 32 (Table A1). The minimum number of a non-terminal node was selected as two since this number was reported to enable decision trees to grow to their full sizes, thus yielding the best results with RF (Luo et al., 2004).

The artificial intelligence and machine-learning algorithms are referred to as the black-box models whose inputs and outputs are well observed. But their internal structures are either not well or not at all understood. Therefore, the interpretability of the RF models was introduced using their following two outputs based on the OBB validation dataset: (1) predictive performance, and (2) normalized relative variable importance. Area under a receiver operation characteristic (ROC) curve (AUC), lift, and overall misclassification rate were used to evaluate the performance of the $17 \mathrm{RF}$ classification models. The scale- and classification-threshold-invariant AUC value varies between 0 (100\% wrong predictions) and 1 (100\% correct predictions). Lift measures how frequently two independent events are associated with a focus on the most critical $x^{\text {th }}$ percentile of the samples, and thus, indicates the classification efficiency. In this study, the $10^{\text {th }}$ percentile of classification accuracy was adopted to compare against the entire dataset. The lower misclassification rate is also known as generalization error rate shows that the more dependencies or better discriminations between output and inputs take place.

Normalized relative variable importance was ranked using the permutation and Gini methods. The permutation variable importance metric was determined monitoring changes in the predictive power of the RF models in response to the shuffling of withincolumn values of each predictor at a time, regardless of what predictors were internally used in the model. The (internal) Gini method describes the role of predictors in the model in the way that the model was constructed. The 17 RF binary classification models were built using Salford Predictive Modeler $®$ RandomForests $®$ 8.3. The alternative hypotheses posed to capture the differences among the characteristics of family businesses, family employees, and FBOs for the 17 responses were tested using Chi-square goodness-of-fit test based on the normalized variable importance scores. Minitab 17 was used in this analysis. 


\section{Results}

A total of 49 variables (17 responses and 32 predictors), and their observed levels, frequencies and maximum entropy values are described in Table $A 1(N=53)$. Entropy measures the degree of uncertainty (information availability) in a random variable. It ranges from 0 for a homogenous dataset when no information is needed (predictability peaks) to 1 for a perfectly random dataset when unpredictability (information needed) peaks. In our dataset, the maximum entropy value varied between 0.23 for honesty (QMS1) as the successor quality that FBOs seek and 1.0 for the fields of business activity (BAC). The response rate for the 49 questions was between $100 \%(N=53)$ and $30.2 \%(N$ $=16)$.

Since the dataset did not meet the parametric test assumptions based on AndersonDarling test, the two non-parametric correlation matrices of Spearman and Kendall Tau-b were used as the more robust measures of linear relationships among the categorical variables. These correlation matrices use different logics to measure the correlation. Although the two matrices had very similar $r$ values, the Spearman's $r$ values (Figure A1) were slightly higher than the Kendall Tau-b ones (Figure A2).

Therefore, only Spearman's $r$ values were reported for the remaining response variables other than FBOs' willingness to transfer to successors (TFM). FBOs' TFM differed significantly between the two cities and was higher in Ardahan than Sivas $(r=0.50 ; P<$ 0.05 for both tests) (Figures A1 and A2). FBO's TFM was most strongly correlated with the FBOs' attitudes of sharing experiences (ATF2) and supervision (TAT3) during succession negatively $(r=-0.79)$ and with the partner availability (PAV) and the presence of non-family managers (NFM) positively $(r=0.63)(P<0.05)$ (Table 2$)$.

Among the 16 qualities that FBOs sought in successors (QMS1 to 16), the strongest negative correlation was found between successor's commitment to the family business (QMS2), entrepreneurship (QMS3) and past performance (QMS11) and the FBOs' attitude of on-site training during succession (TAT1) $(r=-1.0 ; P<0.05)$ (Table 2). Likewise, the strongest positive correlation existed between successor's gender (QMS14) and on-site training during succession (TAT1) $(r=1.0 ; P<0.05)$ (Table 2). In the strongest negative correlations with the QMS1 to 16 , the most frequently used predictor was the FBO attitudes in the succession of sharing experiences (ATF2) and supervision (TAT3) $(29.4 \%)$ followed by on-site training by FBOs (TAT1) and FBOs' actively working (TAT4) (23.5\%) (Table 2). For the strongest positive correlations, the most frequent predictor was the job task definition of family employees (FME8), partner availability (PAV), and transfer of rights before death (TAT5) (23.5\%) (Table 2). 
Table 2 | Maximum correlation coefficient ( $r$ ) values of Spearman's rank-order test between 17 response variables and the remaining variables

\begin{tabular}{|c|c|c|}
\hline \multirow{2}{*}{ Response variable } & \multicolumn{2}{|c|}{ Max $r$ values } \\
\hline & Negative & Positive \\
\hline \multirow[t]{2}{*}{ TFM } & -0.790 & 0.632 \\
\hline & TAT3-ATF2 & PAV-NFM \\
\hline \multirow[t]{2}{*}{ QMS1 } & -0.693 & 0.480 \\
\hline & FME1 & FME6 \\
\hline \multirow[t]{2}{*}{ QMS2 } & -1.0 & 0.661 \\
\hline & TAT1 & ATF4 \\
\hline \multirow[t]{2}{*}{ QMS3 } & -1.0 & 0.661 \\
\hline & TAT1 & ATF4 \\
\hline \multirow[t]{2}{*}{ QMS4 } & -0.395 & 0.395 \\
\hline & BLS-TAT3-4-6-ATF2-3 & TAT5 \\
\hline \multirow[t]{2}{*}{ QMS5 } & -0.500 & 0.632 \\
\hline & TAT2 & GRA \\
\hline \multirow[t]{2}{*}{ QMS6 } & -0.395 & 0.316 \\
\hline & GRA-TAT3-4-ATF2 & BLS-PAV-NFM-FME8-TAT6-ATF3 \\
\hline \multirow[t]{2}{*}{ QMS7 } & -0.395 & 0.395 \\
\hline & $\begin{array}{l}\text { BLS-TAT3-4-6-ATF2- } \\
\quad 3\end{array}$ & TAT5 \\
\hline \multirow[t]{2}{*}{ QMS8 } & -0.395 & 0.316 \\
\hline & GRA-TAT3-4-ATF2 & BLS-PAV-NFM-FME8-TAT6-ATF3 \\
\hline \multirow[t]{2}{*}{ QMS9 } & -0.755 & 0.755 \\
\hline & TAT2 & NFMC-TIM \\
\hline \multirow[t]{2}{*}{ QMS10 } & -0.790 & 0.632 \\
\hline & BLS-TAT1-ATF3 & PAV-NFM-FME8 \\
\hline \multirow[t]{2}{*}{ QMS11 } & -1.0 & 0.661 \\
\hline & TAT1 & ATF4 \\
\hline \multirow[t]{2}{*}{ QMS12 } & -0.800 & 0.800 \\
\hline & FME7 & PAV-NFM-FME8 \\
\hline \multirow[t]{2}{*}{ QMS13 } & -0.395 & 0.557 \\
\hline & ATF4 & TAT1-GRA-ATF3 \\
\hline \multirow[t]{2}{*}{ QMS14 } & -0.661 & 1.0 \\
\hline & ATF4 & TAT1 \\
\hline \multirow[t]{2}{*}{ QMS15 } & -0.294 & 0.412 \\
\hline & ATF1 & BEY-FME1 \\
\hline \multirow[t]{2}{*}{ QMS16 } & -0.632 & 0.755 \\
\hline & PAV-NFM-FME8 & TAT1 \\
\hline
\end{tabular}

Source: authors

Based on the OOB validation dataset, the ROC-AUC metric varied between 0.47 ( 0.13 to 0.82 at $95 \%$ confidence limit) for birth order of heirs (QMS15) and 0.80 (0.68 to 0.92 at $95 \%$ confidence limit) for sub-share size of ownership (QMS16) (Table A3). As the ROCAUC value reaches unity, the RF classification models have a better discrimination ability. The lift value of the most critical $10^{\text {th }}$ percentile ranged from 0.0 for successor honesty (QMS1) to 4.4 for the successor's ability to solve problems (QMS6) among the 17 models (Table A3). The higher the lift value is, the better the model performance is. The overall misclassification rate of the $17 \mathrm{RF}$ models changed between a minimum of 0.26 for both FBOs' willingness to transfer to a successor (TFM) and successor seniority (QMS13) and a maximum of 0.57 for successor's trustworthiness (QMS7) (Table A3).

The overall classification accuracy according to the confusion matrices of the 17 model outcomes varied between $11.3 \%$ for successor's birth order (QMS15) and $64.2 \%$ for successor's respectability (QMS10) (Table A4). The second-best classification accuracy 
belonged to FBO's willingness to transfer to a successor (TFM) (62\%). Out of the 16 successor qualities, the successor's creativity (QMS8) had the second-worst classification accuracy (15.1\%) (Table A4).

The normalized scores (between 0 and 100\%) of relative predictor importance are provided for the $17 \mathrm{RF}$ classification models in Table A5 based on the two methods of the RF algorithm: (1) permutation, and (2) Gini. The Gini method shows the relative importance of the internal predictors of the models in the way that the models were constructed. However, the permutation method quantifies the relative importance by monitoring the impact of randomly shuffling values of each predictor in itself on the model performance, regardless of the internal model predictors and coefficients used. If a certain variable is important, then randomly permuting the order of its values reduces the model accuracy. Hence, the permutation method may as well be considered a sensitivity analysis since the more sensitive the model performance is to a given predictor, the higher its relative importance is. Furthermore, it captures not only main (individual predictor) effects but also interaction effects when the non-linear mechanisms are involved in the prediction of events. It is because if an interaction between two or more predictors exists, then permuting one of the variables in the interaction decreases the predictive power of the interaction, and thus, the model which in turn shows up as important in RF.

Based on the permutation method, the most important and sensitive predictors that were most likely to interact are presented in Table A5 for each of the 17 RF classification models. The most frequent predictor of the relatively most important predictors across the 17 RF classification models was found as FBO's education level (EDU, 25.3\%) and successor's on-site training by FBO (TAT1, 17.7\%) for the Gini and permutation methods, respectively (Table A5). There were the following six RF classification models out of 17 that had the same most important variables according to both approaches: FBO's education (EDU) for successor's trustworthiness (QMS7) and creativity (QMS8); successor's on-site training by FBO (TAT1) for successor's past performance (QMS11); family employee's job task definition (FME8) for successor's past performance (QMS11); business establishment year (BEY) for successor's birth order (QMS15); and business location (CITY) for successor's sub-share size of ownership (QMS16). The most frequent predictors of the least important predictors among the $17 \mathrm{RF}$ classification models were successor's (out-of-)job experience (FME7), successor's gender (GEN), the number of non-family managers (NFMC), and transfer of rights to successors before FBO's death (TAT5) (11.8\%) according to the permutation method, and successor's gender (GEN, $70.6 \%$ ) according to the Gini method.

As for the testing of the alternative hypotheses $\left(\mathrm{H}_{\mathrm{a} 1}\right)$ for the 17 responses, Chi-square goodness-of-fit test was performed to compare the observed distributions of the variable importance of the three predictor classes ( $1=$ the FBO attributes; 2 = the family employee attributes; 3 = the family business attributes) for each RF model to their expected uniform distribution under the assumption that the three classes had equal probability. Based on the extent to which the observed distribution of the normalized variable importance scores varied from the hypothesized distribution, the higher proportions of the predictor class of the FBO's attributes were significantly observed in the 14 RF models (TFM, and QMS1 to QMS13) out of $17(P=0.001)$. In the remaining three RF models, the higher proportion 
belonged to the predictor class of the business attributes in shaping how much FBOs valued successor's gender (QMS14) $(P=0.002)$ and birth order (QMS15) $(P=0.001)$, and to that of the family employee's attributes in determining how much FBOs valued successor's share of ownership (QMS16) $(P=0.001)$.

\section{Discussion}

Single decision trees can also be established using various methods such as classification and regression tree (CART), conditional inference trees (CIT), and boosted regression tree (BRT) (Hothorn et al., 2006; Elith et al., 2008). However, RF consists of hundreds of decision trees using a bootstrapped randomization which renders it resistant to perturbations in the training dataset and able to perform better on the validation (unseen) data (Verikas et al., 2011). Understanding of family business-related insights to be derived from the application of RF is still in its infancy due to the very limited existence of practical and academic studies in related literature. For example, Peltonen (2018) found RF models to outperform BRT and artificial neural networks by being able to correctly classify family firms based on survey data from 7.153 European family businesses. Muller et al. (2016) successfully predicted the business volume of small-tomedium-sized enterprises in Switzerland as a function of characteristics of companies and cities in which businesses operated, and their interactions using RF for binary classification of small and large volume companies. They emphasized RF as the state-ofthe-art method in providing a unique combination of prediction accuracy and model interpretability which can serve as the basis for a decision support system.

At the forefront of the FBOs' attitudes in the process of succession were on-site training, supervision, sharing experiences, and actively working. A strong negative correlation of the FBOs' attitude of on-site training was found with the heir or successor qualities of commitment to a family business, entrepreneurship, and past performance (Figures A1 and A2) (Table 2). On-site training was positively associated with male heirs or successors (Figures A1 and A2). Overall, our correlation results in Table 2 and Figures A1 and A2 showed that the FBOs' attitudes of on-site training, supervision, sharing experiences, and actively working in succession lessened with the heir or successor attributes that they considered appropriate.

The permutation method, similar to the logic of the leave-one-out cross-validation, was shown to be a better measure of the relative variable importance than is the Gini method (Strobl et al., 2007). The explanatory variables found to contribute most to segmenting the binary classifications of the 17 response variables can also be considered to lead to the maximum information gain; in other words, the maximum difference in entropies. Strobl et al. (2007) found that the Gini method was biased towards the categorical variables with many distinct values, while the permutation method showed a bias towards correlated variables. In this context, the correlation matrices can also help to mitigate the multicollinearity issue by reducing the possibility of incorporating the highly correlated features in the RF models. 


\section{Limitations and future research directions}

The present study has its limitations in the three main domains. First, the sample size was relatively small when compared to the target population size of 621 and 1562 family businesses officially registered to the Chambers of Commerce and Trade in Ardahan and Sivas, respectively. Therefore, more diverse and larger samples from different geographic regions, sectors, and religious orientations are recommended to obtain more generalizable and transferable results. Second, due to the very private nature of the subject matter, it was complicated to have participators in both cities show a willingness to openly respond to the questions posed in this study. Finally, the (semi-)structured interview and script in qualitative research that takes longer to complete and reveal confidential information generally suffer from validity and reliability. In future studies, other advanced machine-learning algorithms such as gradient boosting machines, and support vector machines remain to be explored in the computational social sciences.

\section{Theoretical and practical conclusions}

In practice, the domain of the FBOs' characteristics was found to have a more profound impact on both FBO's willingness to transfer to a successor and what successor's qualities were most valued than did the domains of the family business and employee characteristics. A total of the $17 \mathrm{RF}$ classification models were constructed and validated for the 17 response variables of the FBOs' willingness to transfer to successors, and what successor's qualities FBOs valued most. The relative importance, sensitivity, and interaction effect of the explanatory variables were detected for each of the 17 response variables. What the present study and other similar studies have in common is the highdimensional data (49 variables in our case) of non-parametric and non-linear nature with small sample sizes, outliers, missing values, and noise. RF was shown to be robust to the complex and dynamic data structures (Bhattacharyya et al., 2011), and thus, how important to maximize the benefit from its use in a better understanding of causal relationships. The theoretical contribution made by this study is related to the data-driven (inductive) nature of the RF algorithm. This machine-learning and the data-mining algorithm used for the classification predictions has the potential to contribute to theory by discovering unknown patterns, drivers and interactions of relationships in the subject matter of the succession process of the family business. The machine-learning algorithms appear to be promising in terms of deriving theoretical and practical insights and strategies from computational social sciences in the era of big data. 


\section{References}

Allio, M. (2004). Family Businesses: Their Virtues, Vices and Strategic Path. Strategy and Leadership, 32(4), 24-33.

ASSBA. (2016)."Key to Sustainable Success of Family Businesses.” Akbank, Manager Development Unit of Sabanci University EDU, Deloitte and TAIDER Association of Family Businesses (ASSBA), Retrieved December 15, 2018, from

https://www2.deloitte.com/content/dam/Deloitte/tr/Documents/risk/aile-sirketlerindesurdurulebilir-basarinin-anahtarlari.pdf

Bau, M., Hellerstedt, K.,Nordqvist, M., \& Wennberg, K. (2013). Succession in Family Firms. In The Landscape of Family Business,167-197. Edward Elgar.

Bhattacharyya, S., Jha, S., Tharakunnel, K.,\& Westland, J. C.(2011). Data Mining for Credit Card Fraud: A Comparative Study. Decision Support Systems, 50(3), 602-613.

Blodgett, M. S., Dumas, C., \& Zanzi, A. (2011). Emerging Trends in Global Ethics: A Comparative Study of U.S. and International Family Values. Journal of Business Ethics, 99, 29-38.

Breiman, L. (2001). Random Forests. Machine Learning, 45(1), 5-32.

Cesaroni, F. M., \& Sentuti, A. (2017). Family Business Succession and External Advisors. The Relevance of "Soft" Issues. Small Enterprise Research, 24(2),167-188.

Chrisman, J. J., Chua, J. H., \& Sharma, P. (1998). Important Attributes of Successors in Family Businesses: An Exploratory Study. Family Business Review,1(11), 19-34.

Chua, J. H., Chrisman, J. J., \& Sharma, P. (1999). Defining the Family Business by Behavior. Entrepreneurship Theory and Practice. 23(4), 19-39.

Chua, J. H., Chrisman, J. J., \& Sharma, P. (2003). Succession and Nonsuccession Concerns of Family Firms and Agency Relationship with Nonfamily Managers. Family Business Review, 16(2), 89-107.

De Massis, A., Chua, J. H., \& Chrisman, J. J. (2008). Factors Preventing Intra-Family Succession. Family Business Review, 2(21), 183-199.

Devany, C. (2006). All in The Family: Succession Planning in A Family Business Is Important for Keeping Family and Business Intact. Journal of Property Management, 71(5), 14-14.

Elith, J., Leathwick, J. R., \& Hastie, T.(2008). A Working Guide to Boosted Regression Trees. The Journal of Animal Ecology, 77(4), 802-813.

Grimmer, J. (2015). We Are All Social Scientists Now: How Big Data, Machine Learning, and Causal Inference Work Together. Political Science \& Politics, 48(1), 80-83.

Gomba, M., \& Kele, T. (2016). Succession Planning in Black-Owned Family Businesses: A South African Perspective. International Journal of Business Administration, 7(5), 9-21.

Güller, S. (2010). The Role of Turnover Planning in Institutionalization of Family Businesses and a Research Istanbul University Institute of Social Sciences. [Master thesis]. Department of Business Administration.

Hacıbayramoğlu, M. G. (2014). The Impact of Succession on Family Business Innovation: A Case Study on Machinery Manufacturing Sector in Ankara, M.Sc., Department of Science and Technology Policy Studies, The Graduate School of Social Sciences of Middle East Technical University 
Hothorn, T., Hornik, K., \& Zeileis, A. (2006). Unbiased Recursive Partitioning: A Conditional Inference Framework. Journal of Computational and Graphical Statistics, 15(3), 651-674.

Jordan, M. I., \& Mitchell, T. M. (2015). Machine Learning: Trends, Perspectives, and Prospects. Science, 349, 255-260.

Laakkonen, A., \& Kansikas, J. (2011). Evolutionary Selection and Variation In Family Businesses. Management Research Review, 34(9), 980-995.

Lazer, D., Pentland, A., Adamic, L., Aral, S., Barabási, A., Brewer, D., \& Christakis, N., et al. (2009). Computational Social Science. Science, 323, 721-723.

Le Breton-Miller, I., Miller, D., \& Steier, L. (2004). Toward an Integrative Model of Effective FOB Succession. Entrepreneurship Theory and Practice, 28, 305-328.

Luo, T., Kramer, K., Goldgof, D. B., Hall, L. O., Samson, S., Remsen, A., \& Hopkins, T. (2004). Recognizing Plankton Images from the Shadow Image Particle Profiling Evaluation Recorder. IEEE Transactions on Systems Man and Cybernetics Part B-Cybernetics, 34(4), 17531762.

Muller, D., Te, F., Meyer, F., \& Cvijikj, I. P. (2016). Towards Data Driven Decision Support for Financial Institutions: Predicting Small Companies' Business Volume in Switzerland. Paper presented at the annual meeting for the $7^{\text {th }}$ International Conference on Computer Science and Information Technology (CSIT), Amman, Jordan, pp. 1-6.

Nordqvist, M., \& Melin, L. (2010). Entrepreneurial families and family firms. Entrepreneurship \& Regional Development, 22(3-4), 211-239.

Peltonen, J. (2018). Can Supervised Machine Learning Be Used to Identify Family Firms Using A Sophisticated Definition? Academy of Management Proceedings, Advance online publication. https://doi.org/10.5465/AMBPP.2018.154.

Sharma, P. (2004). An Overview of the Field of Family Business Studies: Current Status and Directions for the Future. Family Business Review,17(1), 1-36.

Sharma, P., \& Irving, P. G. (2005). Four Bases of Family Business Successor Commitment: Antecedents and Consequences. Entrepreneurship Theory and Practice, 29(1), 13-33.

Sharma, P., \& Rao, A. S. (2000). Successor Attributes in Indian and Canadian Family Firms: A Comparative Study. Family Business Review, 13(4), 313-330.

Strobl, C., Boulesteix, A. L., Zeileis, A., \& Hothorn, T. (2007). Bias in Random Forest Variable Importance Measures: Illustrations, Sources and A Solution. BMC Bioinformatics, 8, 25.

Tucker, J. (2011). Keeping the Business in the Family and the Family in the Business: What is the Legacy? Journal of Family Business, 1(1), 65-73.

Tuncel, H.T. (2011). (Not) Institutionalizing in Family Business. Konya Chamber of Commerce, Survey-Research Service. Retrieved December 15, 2018, from http://www.kto.org.tr/d/file/aile_sirketi_rapor.pdf

Van Praag, C. M., \& Versloot, P. H. (2007). What is the Value of Entrepreneurship? A Review of Recent Research. Small Business Economics, 29(4), 351-382.

Venter, E., Boshoff, C., \& Maas, G. (2005). The Influence of Successor-Related Factors on the Succession Process in Small and Medium-Sized Family Businesses. Family Business Review, 18(4), 283-303. 
Verikas, A., Gelzinis, A., \& Bacauskiene, M. (2011). Mining Data with Random Forests: A Survey and Results of New Tests. Pattern Recognition, 44(2), 330-349.

Yu, A., Lumpkin, G. T., Sorenson, R. L., \& Brigham, K. H. (2012). The Landscape of Family Business Outcomes: A Summary and Numerical Taxonomy of Dependent Variables. Family Business Review, 25, 33-57.

Zehe, A. K. (2016). Three Essay On Family Succession. [Dissertation thesis]. Department of Economics at the Technical University of Munich, 1-172.

The research paper passed the review process. | Received: November 27, 2019; Revised: January 24, 2020; Accepted: February 8, 2020; Published: July 10, 2020. 


\section{Appendices}

Figure A1 | Spearman's rank-order correlation matrix ( $P<0.05$ when $r \geq 0.3$ and -0.3$)$

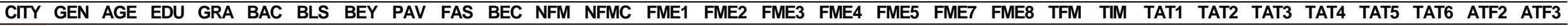
GEN -0.19

AGE $\quad-0.40 \quad 0.74$

EDU $0.20 \quad 0.11 \quad-0.09$

GRA $\quad-0.390 .55 \quad 0.76 \quad-0.43$

$\begin{array}{llllll}\text { BAC } & 0.50 & 0.19 & -0.38 & -0.07 & -0.36\end{array}$

$\begin{array}{lllllll}\text { BLS } & 0.10 & 0.55 & 0.06 & 0.55 & -0.30 & 0.44\end{array}$

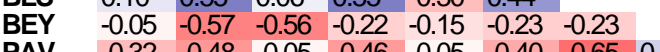

$\begin{array}{llllllll}-0.32 & -0.48 & -0.05 & -0.46 & -0.05 & -0.40 & -0.65 & 0.19\end{array}$

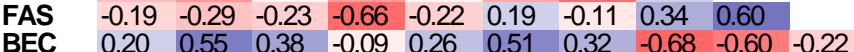

$\begin{array}{llllllllllll}\text { NFM } & -0.32 & -0.48 & -0.05 & -0.46 & -0.05 & -0.40 & -0.65 & 0.19 & 1.00 & 0.60 & -0.60\end{array}$

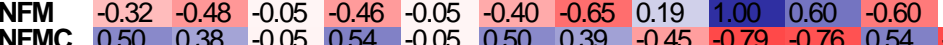

$\begin{array}{llllllllllllll}\text { FFME } & 0.50 & 0.38 & -0.05 & 0.54 & -0.05 & 0.50 & 0.39 & -0.45 & -0.79 & -0.76 & 0.54 & -0.79 & \\ \text { FME } & -0.25 & 0.19 & 0.60 & -0.51 & 0.44 & -0.13 & -0.37 & -0.60 & 0.32 & 0.19 & 0.51 & 0.32 & -0.25\end{array}$

$\begin{array}{llllllllllllll}\text { FME2 } & -0.19 & 0.36 & -0.17 & 0.44 & -0.06 & 0.19 & 0.55 & 0.17 & -0.48 & -0.29 & -0.11 & -0.48 & 0.38\end{array}$

$0.38-0.66$

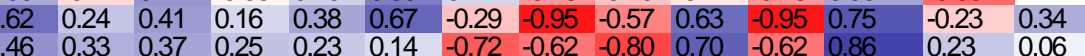

FME5 $0.30 \quad 0.46 \quad 0.34$

$\begin{array}{lllllllllllll}\text { FME7 } & 0.79 & -0.06 & -0.29 & 0.46 & -0.28 & 0.40 & 0.14 & -0.19 & -0.55 & -0.60 & 0.28 & -0.55\end{array}$

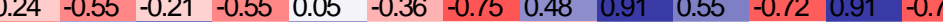

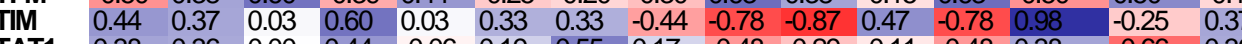

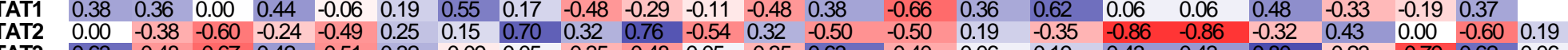

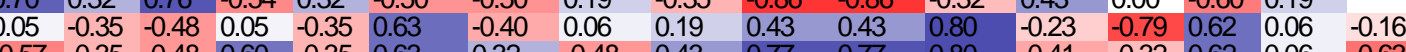

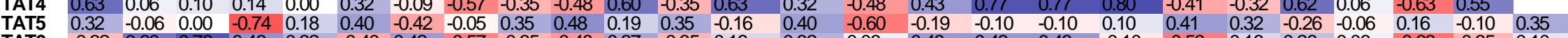

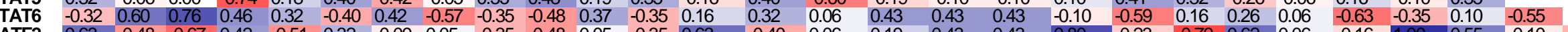

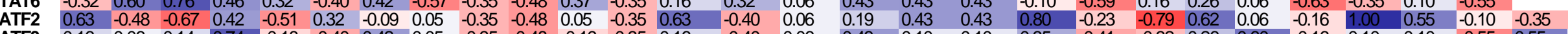

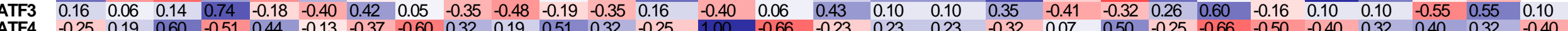

Source: authors 


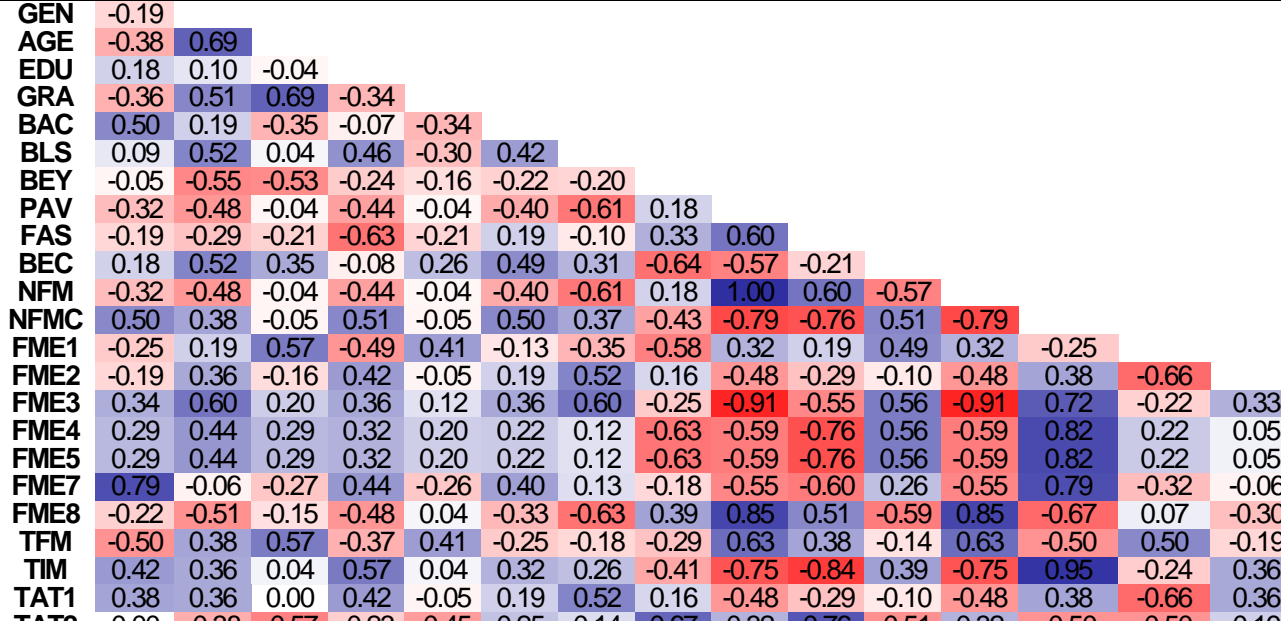


Table A1| Description of response and explanatory variables used in this study $(\mathrm{N}=53)$

\begin{tabular}{|c|c|c|c|c|c|c|c|c|}
\hline No & Symbol & Description & $N$ & $\begin{array}{l}\text { Observed } \\
\text { level }\end{array}$ & $\begin{array}{l}\text { Level } \\
\text { frequency (\%) }\end{array}$ & $\begin{array}{l}\text { Variable } \\
\text { type }\end{array}$ & $\begin{array}{l}\text { Information } \\
\text { classification }\end{array}$ & $\begin{array}{l}\text { Max } \\
\text { entropy }\end{array}$ \\
\hline 1 & GEN & Gender & 53 & 1 Female & 5.7 & Predictor & FBO attribute & 0.31 \\
\hline 2 & AGE & Age & 53 & $\begin{array}{ll}1 & 18-30 \\
2 & 31-40 \\
3 & 41-50 \\
4 & >50\end{array}$ & $\begin{array}{l}y 4.3 \\
7.6 \\
11.3 \\
35.9 \\
45.2\end{array}$ & Predictor & FBO attribute & 0.84 \\
\hline 3 & EDU & Education level & 53 & $\begin{array}{l}\text { Primary } \\
\text { Secondary } \\
\text { High } \\
\text { University } \\
\text { Masters }\end{array}$ & $\begin{array}{l}15.1 \\
17.0 \\
37.7 \\
18.9 \\
11.3\end{array}$ & Predictor & FBO attribute & 0.94 \\
\hline 4 & GRA & Graduation & 16 & $\begin{array}{l}\text { Business/Economics } \\
\text { Engineering } \\
\text { Education } \\
\text { Veterinary } \\
\text { Others }\end{array}$ & $\begin{array}{l}43.8 \\
37.5 \\
6.3 \\
6.3 \\
6.1\end{array}$ & Predictor & FBO attribute & 0.77 \\
\hline 5 & BAC & Activity field & 51 & $\begin{array}{l}\text { Commerce } \\
\text { Service } \\
\text { Manufacturing }\end{array}$ & $\begin{array}{l}33.3 \\
33.3 \\
33.4\end{array}$ & Predictor & Business attribute & 1.0 \\
\hline 6 & CITY & City & 53 & $\begin{array}{l}\text { IVanutacturing } \\
\text { Ardahan }\end{array}$ & $\begin{array}{l}33.4 \\
52.8 \\
472\end{array}$ & Predictor & Business attribute & 0.99 \\
\hline 7 & BLS & Legal status & 45 & $\begin{array}{l}\text { Private Co. } \\
\text { Incorporated Co. } \\
\text { Limited Co. }\end{array}$ & $\begin{array}{l}73.3 \\
4.4 \\
22.3\end{array}$ & Predictor & Business attribute & 0.63 \\
\hline 8 & BEY & Establishment year & 51 & $\begin{array}{l}1920-1950 \\
1951-1980 \\
1981-2000 \\
2001-2018\end{array}$ & $\begin{array}{l}2.0 \\
27.5 \\
39.2 \\
31.3\end{array}$ & Predictor & Business attribute & 0.83 \\
\hline 9 & PAV & Partner availability & 53 & Yes & $\begin{array}{l}20.8 \\
792\end{array}$ & Predictor & Business attribute & 0.73 \\
\hline 10 & FAS & Family ownership share & 51 & $\begin{array}{l}\leq 50 \% \\
>50 \% \leq 99 \% \\
100 \%\end{array}$ & $\begin{array}{l}19.2 \\
2.0 \\
9.8 \\
88.2\end{array}$ & Predictor & Business attribute & 0.37 \\
\hline 11 & BEC & Employee count & 47 & $\begin{array}{l}\text { Non } \\
1-5 \\
6-10 \\
>10\end{array}$ & $\begin{array}{l}4.3 \\
53.2 \\
14.9 \\
27.6\end{array}$ & Predictor & Business attribute & 0.80 \\
\hline 12 & NFM & $\begin{array}{l}\text { Non-family manager } \\
\text { availability }\end{array}$ & 53 & $\begin{array}{l}\text { Yes } \\
\text { No }\end{array}$ & $\begin{array}{l}26.4 \\
73.6\end{array}$ & Predictor & Business attribute & 0.83 \\
\hline 13 & NFMC & Non-family manager count & 52 & 1 & $\begin{array}{l}84.6 \\
15.4\end{array}$ & Predictor & Business attribute & 0.61 \\
\hline 14 & FME1 & Employee count & 43 & $\begin{array}{l}\text { Non } \\
1-5 \\
6-10 \\
>10\end{array}$ & $\begin{array}{l}7.4 \\
7.0 \\
86.1 \\
4.7 \\
2.2\end{array}$ & Predictor & Family employee attribute & 0.39 \\
\hline 15 & FME2 & Gender & 45 & Female & 15.6 & Predictor & Family employee attribute & 0.62 \\
\hline 16 & FME3 & Education & 45 & $\begin{array}{l}\text { Primary } \\
\text { Secondary } \\
\text { High } \\
\text { University }\end{array}$ & $\begin{array}{l}84.0 \\
2.2 \\
13.3 \\
40.0 \\
44.5\end{array}$ & Predictor & Family employee attribute & 0.77 \\
\hline 17 & FME4 & Work period in the place & 45 & $\begin{array}{l}<1 \text { year } \\
1-5 \text { years } \\
6-10 \text { years } \\
11-20 \text { years } \\
>20 \text { years }\end{array}$ & $\begin{array}{l}4.4 \\
22.2 \\
20.0 \\
42.2 \\
11.2\end{array}$ & Predictor & Family employee attribute & 0.87 \\
\hline 18 & FME5 & Work period outside & 43 & $\begin{array}{l}<1 \text { year } \\
1-5 \text { years }\end{array}$ & $\begin{array}{l}25.6 \\
16.3\end{array}$ & Predictor & Family employee attribute & 0.94 \\
\hline
\end{tabular}




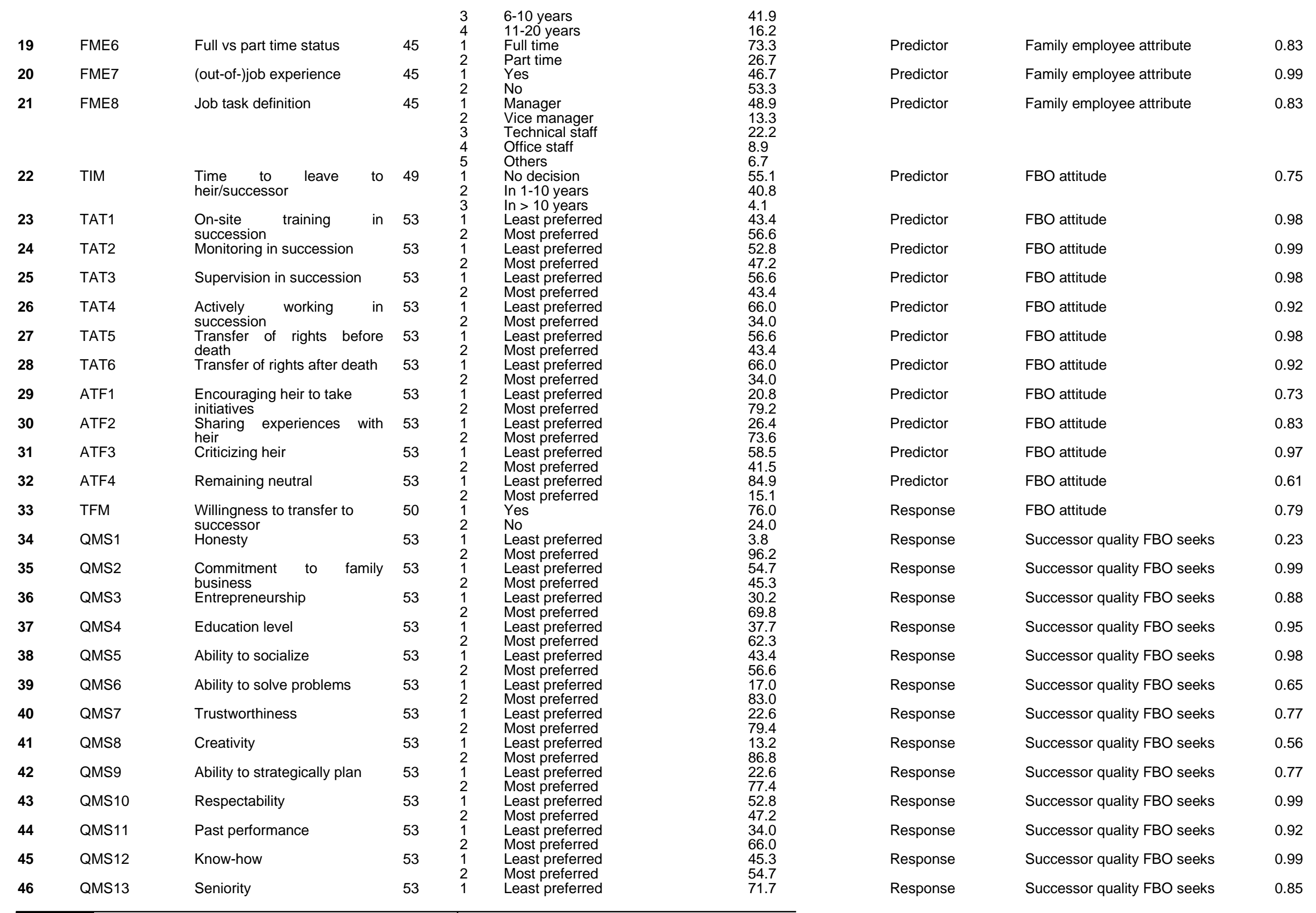




\begin{tabular}{|c|c|c|c|c|c|c|c|c|c|}
\hline 47 & QMS14 & Gender & 53 & $\begin{array}{l}2 \\
1 \\
2\end{array}$ & Most preferred & $\begin{array}{l}28.3 \\
67.9\end{array}$ & Response & Successor quality FBO seeks & 0.90 \\
\hline 48 & QMS15 & Birth order & 53 & 1 & $\begin{array}{l}\text { Mosst prererrea } \\
\text { Least preferred }\end{array}$ & 88.7 & Response & Successor quality FBO seeks & 0.50 \\
\hline 49 & QMS16 & Subshare size & 53 & $\begin{array}{l}2 \\
1 \\
2\end{array}$ & Most preferred & $\begin{array}{l}75.5 \\
24.5\end{array}$ & Response & Successor quality FBO seeks & 0.80 \\
\hline
\end{tabular}

Source: authors

Table A3 | Error measures of $17 \mathrm{RF}$ classification models

\begin{tabular}{|c|c|c|c|c|c|c|c|c|c|c|c|c|c|c|c|c|c|}
\hline ame & TFM & QMS1 & QMS2 & QMS3 & QMS4 & QMS5 & QMS6 & QMS7 & QMS8 & QMS9 & QMS10 & QMS11 & QMS12 & QMS13 & QMS14 & QMS15 & QMS16 \\
\hline C-AUC & 0.60 & 0.76 & 0.69 & $\begin{array}{l}0.61 \\
0.45\end{array}$ & 0.66 & 0.66 & $\begin{array}{l}0.78 \\
0.62\end{array}$ & 0.47 & 0.66 & 0.64 & 0.74 & 0. & 0. & 0.74 & 0.66 & 0.47 & 0.80 \\
\hline limit & 0.4 & 0.53 & 0.55 & 0.45 & 0.52 & 0.51 & 0.6 & 0.29 & 0.47 & 0.43 & 0.60 & 0.44 & 0. & 0. & 0.50 & 0.13 & 0.68 \\
\hline oer contiden & 0.77 & 0.98 & $\begin{array}{l}0.84 \\
114\end{array}$ & $\begin{array}{l}0.78 \\
188\end{array}$ & 0.81 & 0.81 & 0.94 & 0.65 & $\begin{array}{l}0.84 \\
1.43\end{array}$ & $\begin{array}{l}0.86 \\
3.32\end{array}$ & 0.88 & $\begin{array}{l}0.75 \\
111\end{array}$ & 0.74 & 0.8 & 0.81 & 0.82 & 0.92 \\
\hline 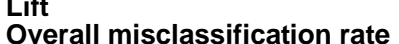 & $\begin{array}{l}1.32 \\
0.26\end{array}$ & $\begin{array}{l}0.00 \\
0.38\end{array}$ & $\begin{array}{l}1.14 \\
0.36\end{array}$ & $\begin{array}{l}1.88 \\
0.49\end{array}$ & $\begin{array}{l}1.00 \\
0.40\end{array}$ & $\begin{array}{l}1.87 \\
0.40\end{array}$ & $\begin{array}{l}4.44 \\
0.30\end{array}$ & $\begin{array}{l}1.67 \\
0.57\end{array}$ & $\begin{array}{l}1.43 \\
0.47\end{array}$ & $\begin{array}{l}3.33 \\
0.40\end{array}$ & $\begin{array}{l}1.43 \\
0.28\end{array}$ & $\begin{array}{l}1.11 \\
0.45\end{array}$ & $\begin{array}{l}1.38 \\
0.42\end{array}$ & $\begin{array}{l}1.13 \\
0.26\end{array}$ & $\begin{array}{l}1.47 \\
0.38\end{array}$ & $\begin{array}{l}0.85 \\
0.34\end{array}$ & $\begin{array}{l}1.33 \\
0.28\end{array}$ \\
\hline
\end{tabular}

Overall misclassification rate

\begin{tabular}{ll}
0.26 & 0.38 \\
\hline
\end{tabular}

Source: authors

Table A4 | Confusion matrices of 17 RF classification models

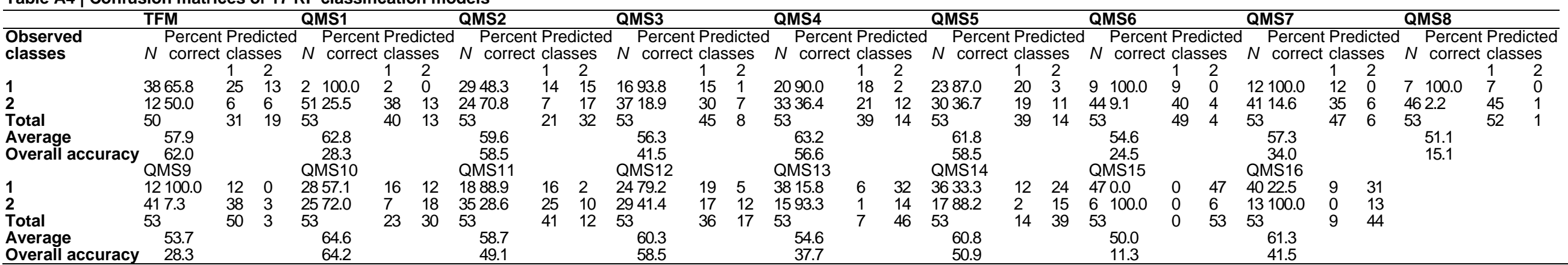

Source: authors 
Table A5 | Normalized scores (\%) of relative predictor importance based on (a) permutation and (b) Gini methods of 17 RF classification models

\begin{tabular}{|c|c|c|c|c|c|c|c|c|c|c|c|}
\hline \multirow{2}{*}{$\begin{array}{l}\text { (a) TFM } \\
\text { GRA } 100.0\end{array}$} & \multirow{2}{*}{$\mid \overline{||||||||||||||||||||||||||||||||||||||||||||||||}$} & \multicolumn{2}{|l|}{ (b) TFM } & \multirow{2}{*}{$\begin{array}{l}\text { (a) QMS1 } \\
\text { TAT 100. }|\|||||||||||||||||||||||||||||||||| \\
1 \quad 0 \quad\|\|\|\|\|\|\|\|\end{array}$} & (b) QMS1 & & \multicolumn{2}{|c|}{ (a) QMS2 } & \multicolumn{3}{|c|}{ (b) QMS2 } \\
\hline & & $\begin{array}{l}\text { FME } 100.0 \\
8\end{array}$ & $|\|||||||||||||||||||||||||||||||||||||||||||||| \mid$ & & FME6 100.0 & 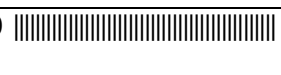 & TAT2 & $\begin{array}{l}100 .|||||||||||||||||||||||||||||||||||||||||||||||| \\
0\end{array}$ & BEC & 100.0 & $\begin{array}{l}|\|\| \|||||||||||||||||||||||||||||| \mid \\
\|\|\|\|\||\||\end{array}$ \\
\hline $\begin{array}{l}\text { FME } 72.2 \\
8\end{array}$ & |||||||||||||||||||||||||||||||||| & GRA 98.9 & |||||||||||||||||||||||||||||||||||||||||||||||| $\mid$ & $\begin{array}{l}\text { FME } 72.1 \mathrm{\|}|\||\||\||\|||||||||||||||||||||||||| \mid \\
3\end{array}$ & TAT1 66.5 & |||||||||||||||||||||||||||||||| & FME4 & 29.1|||||||||||| $\mid$ & TAT2 & 92.0 & 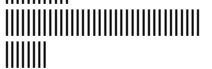 \\
\hline $\begin{array}{l}\text { CIT } 58.4 \\
\text { Y }\end{array}$ & $|\||||||||||||||||||||||||||||$ & EDU 80.0 & |||||||||||||||||||||||||||||||||||||||| $\mid$ & $\begin{array}{l}\text { FME } 64.2|||||||||||||||||||||||||||||| \mid \\
6\end{array}$ & FME4 60.6 & |||||||||||||||||||||||||||||| $\mid$ & GRA & 27.9|||||||||||| $\mid$ & GRA & 82.7 & ${ }_{\|\|\|\|\|\| \|||||||||||||||||||||||||||||}$ \\
\hline BAC 52.5 & $|\|||||||||||||||||||||||| \mid$ & BAC 56.5 & |||||||||||||||||||||||||||| $\mid$ & AGE $57.6|\|||||||||||||||||||||||||| \mid$ & FME5 49.8 & |||||||||||||||||||||||| & BEC & 26.7|||||||||||| $\mid$ & FME4 & 71.9 & ||||||||||||||||||||||||||||||||||| \\
\hline $\begin{array}{l}\text { ATF } 51.2 \\
2\end{array}$ & |||||||||||||||||||||||| & BEY 50.4 & \|\|\|\|\|\|\|\|\|\|\|\|\|\|\|\|$\| \mid$ & EDU 45.1 |\|\|\|\|\|\|\|\|\|\|\|\|\|\|\|| & AGE 34.3 & \|\|\|\|\|\|\|\|\|\|$\| \mid$ & ATF3 & 26.3|||||||||||| & TIM & 61.8 & $|\||||||||||||||||||||||||||||$ \\
\hline EDU 38.3 & $|\|||||||||||||||| \mid$ & AGE 48.7 & |||||||||||||||||||||| $\mid$ & $\begin{array}{l}\text { FME } 39.4\|\||||||||||||||||| \mid \\
1\end{array}$ & FME3 31.9 & |||||||||||||| $\mid$ & TAT3 & 24.3|||||||||| $\mid$ & FME8 & 51.0 & |||||||||||||||||||||||| \\
\hline TIM 30.9 & $|\|||||||||||| \mid$ & CITY 48.0 & |||||||||||||||||||||||| & PAV 23.3 ||||||||||| & TIM 30.4 & |||||||||||||| $\mid$ & BAC & 22.1|||||||||| $\mid$ & ATF3 & 51.0 & |||||||||||||||||||||||||| \\
\hline $\begin{array}{l}\text { FME } 30.4 \\
1\end{array}$ & \|\|\|\|\|\|\|\|$\| \mid$ & $\begin{array}{l}\text { FME } 45.7 \\
3\end{array}$ & $|\|||||||||||||||||| \mid$ & $\begin{array}{l}\text { TAT } 22.2\|\|\|\|\|\| \| \mid \\
3\end{array}$ & ATF3 20.5 & \|\|\|\|\|\| $\mid$ & FME5 & 17.5|||||||| $\mid$ & FME5 & 49.8 & \|\|\|\|\|\|\|\|\|\|\|\|\|\|\|\| $\mid$ \\
\hline $\begin{array}{l}\text { TAT } 23.1 \\
3\end{array}$ & \|\||||||||| & $\begin{array}{l}\text { ATF } 39.2 \\
2\end{array}$ & $|\||||||||||||||||$ & BAC $13.5 \mid\|\| \|$ & FME1 20.0 & \|\||||||| & TIM & 16.1|||||| $\mid$ & EDU & 49.2 & |||||||||||||||||||||| $\mid$ \\
\hline NFM 19.8 & |||||||| $\mid$ & $\begin{array}{l}\text { FME } 37.7 \\
4\end{array}$ & |||||||||||||||| $\mid$ & BEC $13.1 \mid\|\| \|$ & EDU 20.0 & |||||||| $\mid$ & FME3 & 14.0|||||| & AGE & 47.4 & |||||||||||||||||||||| \\
\hline BEY 19.5 & \|\|\|\|\|\| & $\begin{array}{l}\text { FME } 36.7 \\
5\end{array}$ & |||||||||||||||| $\mid$ & $\begin{array}{l}\text { FME } 7.4 \quad \| \mid \\
8\end{array}$ & BEC 18.1 & |||||||| & ATF2 & $13.2|\||\||$ & BEY & 38.1 & $|\|||||||||||||||| \mid$ \\
\hline $\begin{array}{l}\text { FME } 19.3 \\
3\end{array}$ & $|\|||||| \mid$ & $\begin{array}{l}\text { FME } 36.1 \\
1\end{array}$ & |||||||||||||||||| & $\begin{array}{l}\text { TAT } 2.8 \quad \mid \\
6\end{array}$ & TAT2 15.8 & |||||| $\mid$ & TAT6 & 13.1|||||| & FME3 & 35.9 & $|\|||||||||||||| \mid$ \\
\hline $\begin{array}{l}\text { NFM } 18.4 \\
\text { C }\end{array}$ & \|\||||| $\mid$ & $\begin{array}{l}\text { TAT } 23.6 \\
3\end{array}$ & $|\|||||||| \mid$ & $\begin{array}{l}\text { TAT } 2.3 \quad \mid \\
5\end{array}$ & CITY 14.8 & $|\||||||$ & TAT1 & $9.3 \quad||||$ & TAT3 & 35.7 & $|\|||||||||||||| \mid$ \\
\hline BLS 11.6 & \|\|$\|$ & $\begin{array}{l}\text { ATF } 17.7 \\
3\end{array}$ & \|\|\|\|$\| \mid$ & & BAC 12.3 & |||| $\mid$ & FME1 & $8.6 \quad|\||$ & BAC & 32.6 & $|\||||||||||||||$ \\
\hline AGE 11.5 & \|\|$\|$ & TIM 16.9 & $|\||||||$ & & ATF1 10.7 & $|\|\||$ & PAV & $8.21 \|$ & TAT1 & 30.1 & $|\||||||||||||||$ \\
\hline $\begin{array}{l}\text { TAT } 11.0 \\
5\end{array}$ & \|\|$\|$ & BEC 16.9 & \|\|\|\|$\|$ & & BLS 10.1 & \|\|$\|$ & TAT4 & $7.4 \|$ & ATF1 & 24.6 & \|\|\|\|\|\|$\|$ \\
\hline $\begin{array}{l}\text { FME } 10.8 \\
5\end{array}$ & \|\|$\|$ & $\begin{array}{l}\text { ATF } 12.9 \\
4\end{array}$ & \|\|\|\| & & TAT3 9.0 & ||l| & FME7 & $5.9 \|$ & FME1 & 23.6 & |||||||||| $\mid$ \\
\hline BEC 9.6 & \|\|$\|$ & $\begin{array}{l}\text { TAT } 12.3 \\
4\end{array}$ & \|\|$\|$ & & FME7 8.9 & |||| & FME2 & $3.4 \mid$ & TAT5 & 21.7 & $|\|||||||| \mid$ \\
\hline $\begin{array}{l}\text { ATF } 9.5 \\
3\end{array}$ & \|\|$\|$ & $\begin{array}{l}\text { NFM } 11.9 \\
\text { C }\end{array}$ & \|\|$\|$ & & FME8 8.0 & || & ATF1 & $3.4 \mid$ & ATF2 & 19.8 & |||||||| $\mid$ \\
\hline $\begin{array}{l}\text { FME } 9.3 \\
4\end{array}$ & \|\|$\|$ & NFM 10.9 & \|\|$\|$ & & BEY 7.2 & || & TAT5 & $3.1 \mid$ & NFM & 19.5 & $|\|||||| \mid$ \\
\hline $\begin{array}{l}\text { TAT } 8.8 \\
4\end{array}$ & \|\|$\|$ & $\begin{array}{l}\text { TAT } 10.5 \\
5\end{array}$ & \|\|$\|$ & & TAT4 6.2 & $\|$ & NFMC & 2.31 & TAT6 & 18.6 & $\||||||| \mid$ \\
\hline FAS 7.2 & $\| \mid$ & $\begin{array}{l}\text { TAT } 10.2 \\
2\end{array}$ & |||| & & ATF2 6.1 & $\|$ & FAS & 1.8 & NFMC & 16.0 & $|\||||||$ \\
\hline PAV 6.4 & $\|$ & PAV 10.2 & $|\||$ & & TAT6 3.3 & I & NFM & 0.4 & FME6 & 13.9 & \|\|\|\| \\
\hline GEN 5.0 & $\|$ & BLS 10.0 & |||| $\mid$ & & NFM 2.9 & & & & CITY & 13.6 & \|\|\|\|$\|$ \\
\hline $\begin{array}{l}\text { TAT } 3.3 \\
1\end{array}$ & l & FAS 9.7 & ||l| & & TAT5 2.8 & i & & & PAV & 13.2 & \|\|\|\| \\
\hline $\begin{array}{l}\text { FME } 3.2 \\
7\end{array}$ & | & $\begin{array}{l}\text { TAT } 9.5 \\
6\end{array}$ & $|\||$ & & FME2 2.5 & | & & & TAT4 & 12.0 & \|\|$\| \mid$ \\
\hline $\begin{array}{l}\text { TAT } 2.5 \\
6\end{array}$ & | & $\begin{array}{l}\text { ATF } 9.0 \\
1\end{array}$ & $|\||$ & & FAS 1.4 & & & & BLS & 11.5 & \|\|$\| \mid$ \\
\hline $\begin{array}{l}\text { FME } 2.3 \\
6\end{array}$ & | & $\begin{array}{l}\text { TAT } 8.8 \\
1\end{array}$ & \|\|$\|$ & & PAV $\quad 0.7$ & & & & FAS & 11.1 & \|\|$\|$ \\
\hline
\end{tabular}




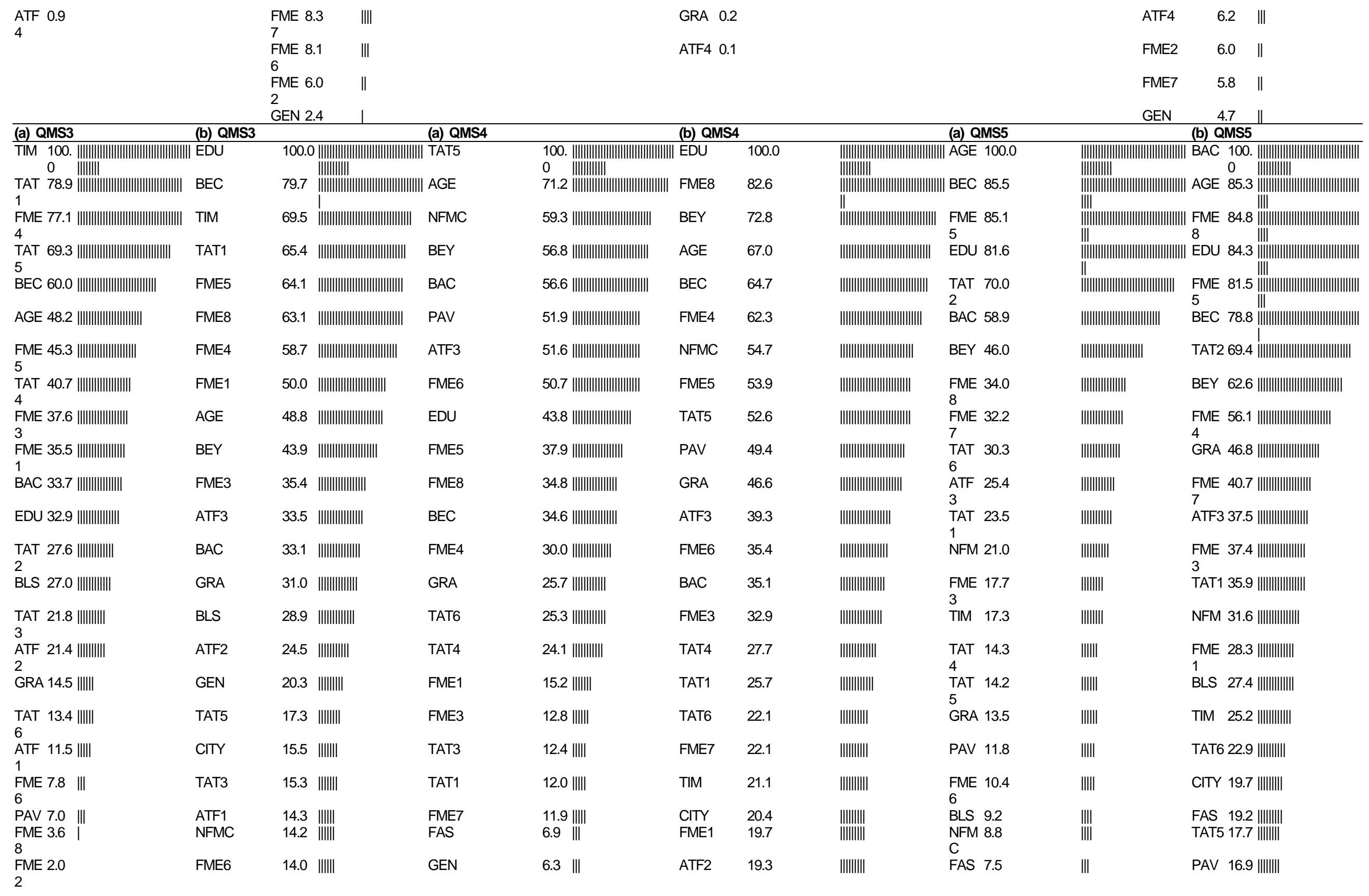




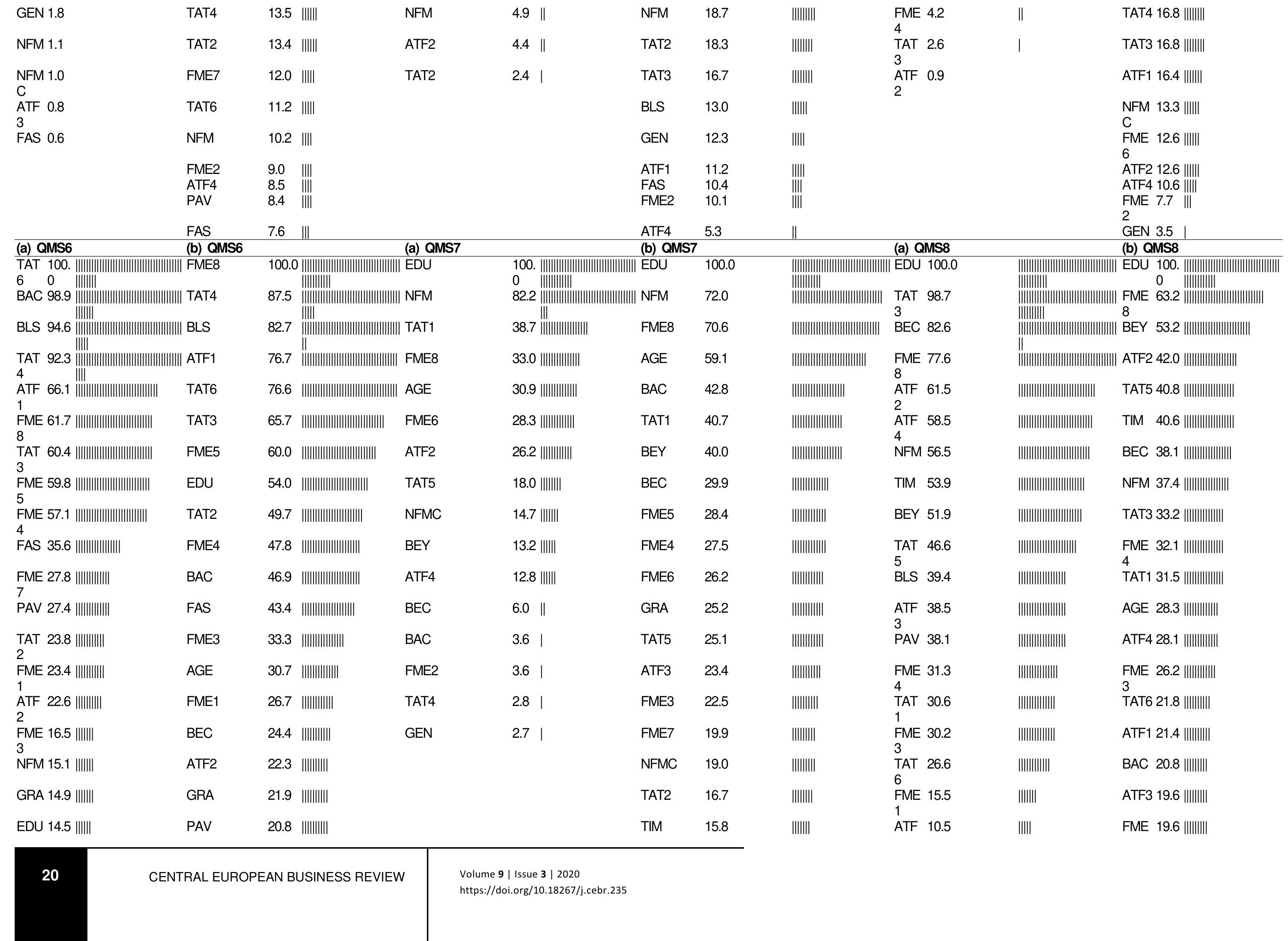




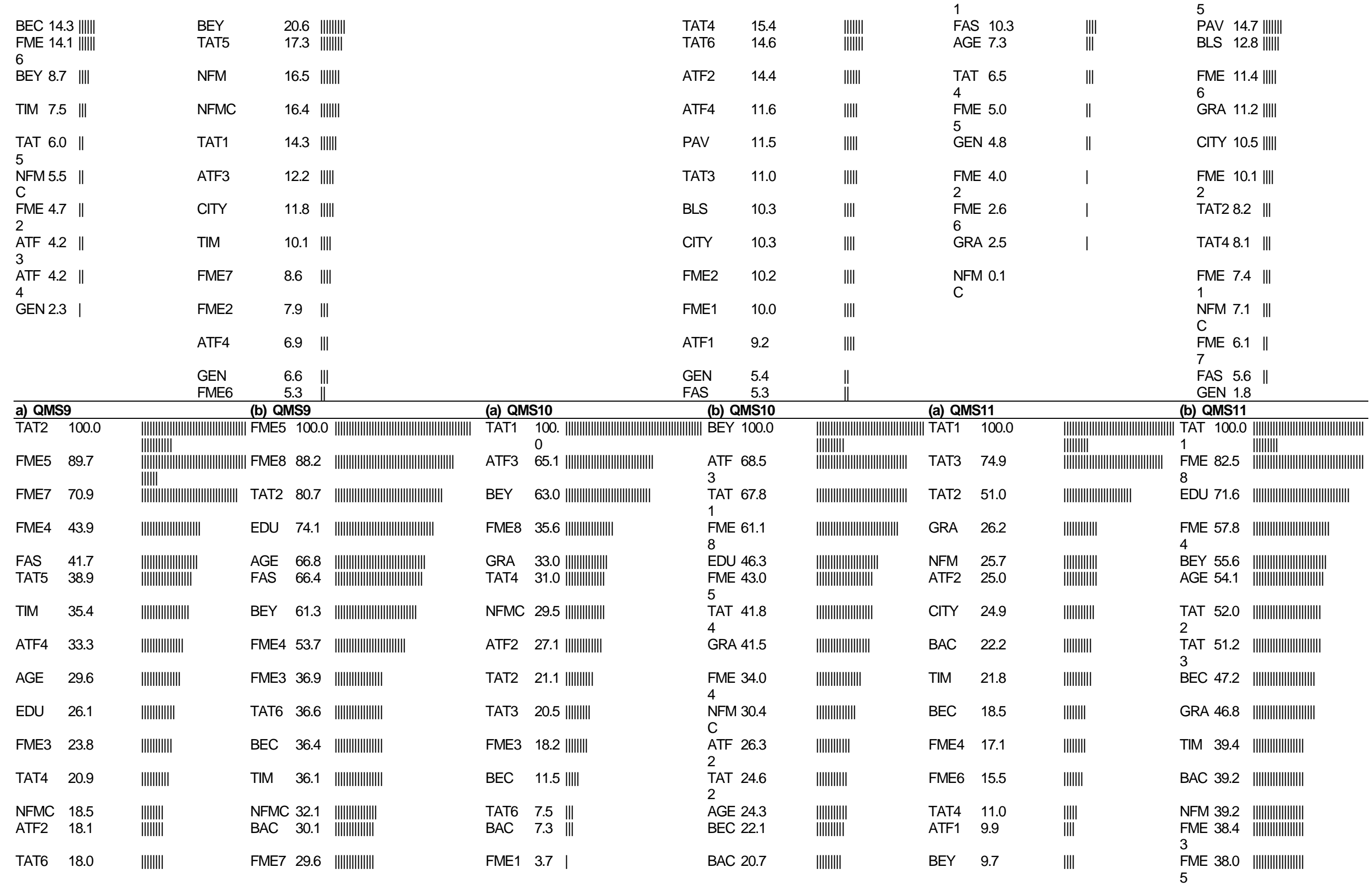




\begin{tabular}{|c|c|c|c|c|c|c|c|c|c|c|c|c|c|c|c|}
\hline BEY & 17.6 & \|\|\|\|$\|$ & TAT5 & $5 \quad 29.5$ & $|\||||||||||||$ & PAV & $2.8 \mid$ & $\begin{array}{l}\text { TAT } \\
3\end{array}$ & 20.5 & $|\||||||||$ & FME2 & 8.1 & || & $\begin{array}{l}\text { ATF } 36.8 \\
2\end{array}$ & |||||||||||||||||| \\
\hline NFM & 17.4 & \|\|\|\|$\| \mid$ & BLS & 28.8 & |||||||||||| $\mid$ & NFM & $2.6 \mid$ & $\begin{array}{l}\text { FME } \\
3\end{array}$ & 19.7 & \|\|\|\||| $\mid$ & FME3 & 6.9 & || & CITY 34.6 & |||||||||||||||| $\mid$ \\
\hline ТАТЗ & 13.6 & ||l||| & ATF4 & $4 \quad 24.4$ & $|\||||||||||$ & TAT5 & $2.2 \mid$ & $\begin{array}{l}\text { FME } \\
1\end{array}$ & 18.1 & \|\|\|\||| & FME8 & 5.6 & $\|$ & $\begin{array}{l}\text { ATF } 25.7 \\
1\end{array}$ & $|\||||||||||$ \\
\hline BEC & 12.5 & ||l||| & GRA & 24.1 & $|\||||||||||$ & FME7 & 2.0 & TIM & 13.8 & \|\|\|\| & FME7 & 4.9 & $\|$ & $\begin{array}{l}\text { FME } 20.1 \\
6\end{array}$ & \|\|\|\|$\|||$ \\
\hline TAT1 & 12.3 & \|\|$\|$ & ATF2 & 23.2 & $|\||||||||||$ & FME2 & 1.6 & $\begin{array}{l}\text { TAT } \\
5\end{array}$ & 11.6 & \|\|$\|$ & TAT5 & 4.0 & I & $\begin{array}{l}\text { FME } 18.7 \\
1\end{array}$ & \|\|\|\|$\| \mid$ \\
\hline BLS & 12.0 & \|\|$\|$ & ATF1 & 121.8 & $|\|||||||| \mid$ & FME5 & 0.1 & $\begin{array}{l}\text { TAT } \\
6\end{array}$ & 11.2 & \|\|$\|$ & ATF4 & 1.1 & & $\begin{array}{l}\text { TAT } 18.4 \\
6\end{array}$ & |||||||| \\
\hline FME6 & 10.3 & $|\||$ & FME6 & $6 \quad 21.7$ & $|\||||||||$ & & & $\begin{array}{l}\text { ATF } \\
1\end{array}$ & 10.3 & |||| & FME1 & 0.6 & & $\begin{array}{l}\text { TAT } 17.0 \\
5\end{array}$ & $\|||||||$ \\
\hline FME2 & 10.2 & $|\||$ & FME2 & 219.4 & \|\|$\||||| \mid$ & & & $\begin{array}{l}\text { FME } \\
6\end{array}$ & 9.5 & |||| & & & & $\begin{array}{l}\text { TAT } 14.7 \\
4\end{array}$ & ||||||| \\
\hline FME8 & 9.4 & \|\|$\|$ & FME1 & 117.9 & $|\||||||$ & & & $\begin{array}{l}\text { FME } \\
2\end{array}$ & & |||| & & & & BLS 13.2 & $|\||||$ \\
\hline BAC & 4.7 & $\|$ & NFM & 15.7 & \|\|\|\| $\mid$ & & & CITY & 8.6 & |||| & & & & $\begin{array}{l}\text { ATF } 12.8 \\
3\end{array}$ & \|\|$\| \mid$ \\
\hline \multirow[t]{8}{*}{ GRA } & 0.8 & & TAT4 & $4 \quad 15.6$ & $|\|||| \mid$ & & & BLS & 7.6 & ||| & & & & $\begin{array}{l}\text { FME } 12.5 \\
2\end{array}$ & ||||| \\
\hline & & & TAT3 & $\begin{array}{ll}3 & 13.3\end{array}$ & ||l||| & & & NFM & 17.4 & || & & & & $\begin{array}{l}\text { ATF } 11.3 \\
4\end{array}$ & ||||| \\
\hline & & & ATF3 & $\begin{array}{ll}3 & 12.8\end{array}$ & ||l||| & & & PAV & 7.0 & $\| \mid$ & & & & $\begin{array}{l}\text { FME } 11.2 \\
7\end{array}$ & ||||| \\
\hline & & & TAT1 & $1 \quad 11.9$ & \|\|$\| \mid$ & & & $\begin{array}{l}\text { FME } \\
7\end{array}$ & 6.6 & ||| & & & & $\begin{array}{l}\text { NFM } 9.3 \\
\text { C }\end{array}$ & |||| \\
\hline & & & CITY & 10.9 & $|\|\||$ & & & FAS & 6.5 & || & & & & FAS 9.3 & |||| \\
\hline & & & PAV & 9.1 & |||| $\mid$ & & & $\begin{array}{l}\text { ATF } \\
4\end{array}$ & 5.1 & $\|$ & & & & PAV 9.0 & ||l| \\
\hline & & & GEN & 4.5 & $\|$ & & & GEN & 2.7 & 1 & & & & GEN 5.5 & $\|$ \\
\hline & (a) QMS12 & & \multicolumn{2}{|c|}{ (b) QMS12 } & & \multicolumn{2}{|l|}{ (a) QMS13 } & (b) $\mathrm{QM}$ & S13 & & \multicolumn{2}{|c|}{ (a) QMS14 } & \multicolumn{3}{|c|}{ (b) QMS14 } \\
\hline FME8 & \begin{tabular}{l|l}
100. & \\
0
\end{tabular} & $\begin{array}{l}|\|||||||||||||||||||||||||||||||||||||||||| \mid \\
|\|| \mid\end{array}$ & | FME8 & $\begin{array}{l}100 .|\||\|| \mid \\
0\end{array}$ & |||||||||||||||||||||||||||||||||||||||||||||| & AGE & $\begin{array}{l}100 .|||||||||||||||||||||||||||||||||||||||||||||| \mid \\
0\end{array}$ & EDU & 100.0 & ${ }_{\mid}^{|\||||||||||||||||||||||||||||||||||||||||||||||}$ & ATF3 & 100.0 & $\begin{array}{l}|\|\|\|\|||||||||||||||||||||||||||||||||||| \\
\|\|\|\| \|\end{array}$ & EDU 100.0 & |||||||||||||||||||| \\
\hline TAT1 & 91.6 & $|\|||||||||||||||||||||||||||||||||||||||||| \mid$ & FME5 & 78.3|||||| & |||||||||||||||||||||||||||||||||| & EDU & 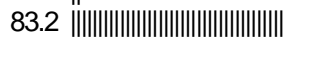 & AGE & 81.8 & |||||||||||||||||||||||||||||||||||||||||| $\mid$ & BEC & 65.9 & $|\||||||||||||||||||||||||||||||$ & BEY $97.6 \|$ & |||||||||||||||||||||||||||||||||||||||||| \\
\hline ATF3 & 52.6 & 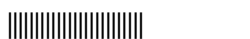 & EDU & 68.9\|\|\|\| & 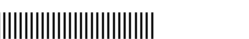 & FME8 & 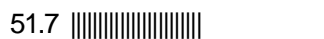 & FME8 & 70.6 & 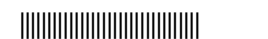 & $\mathrm{BEY}$ & 61.7 & 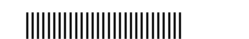 & ATF3 83.4 & 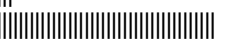 \\
\hline GRA & 33.3 & \|\|\|\|\|\|\|\|\|\||| & TAT1 & $67.5 \mid\|\|\|\|$ & 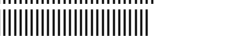 & $\mathrm{BEC}$ & 47.5\|\|\|\|\|\|\|\|\|\|\|\|\|\|\|\|$\|$ & CITY & 58.4 & \|\|\|\|\|\|\|\|\|\|\|\|\|\|\|\|\|\|\|\| $\mid$ & FME5 & 51.0 & \|\|\|\|\|\|\|\|\|\|\|\|\|\|\|\| & BEC 76.5 & 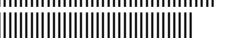 \\
\hline FME4 & 30.7 & \|\|\|\|\|\|\|\|$\|$ & FME4 & 56.8\|\|\|\| & \|\|\|\|\|\|\|\|\|\|\|\|\|\| & ATF3 & 45.8\|\|\|\|\|\|\|\|\|\|\|\|\|\|$\|$ & FME5 & 48.1 & \|\|\|\|\|\|\|\|\|\|\|\|\|\|$\|$ & BAC & 50.7 & \|\|\|\|\|\|\|\|\|\|\|\|\|\|$\|$ & BAC $75.9 \|$ & - \\
\hline TAT3 & 29.8 & \|\|\|\|\|\|\|\|$\|$ & GRA & 51.6\|\|\|\| & \|\|\|\|\|\|\|\|\|\|\|\| & TAT5 & 34.5\|\|\|\|\|\|\|\|\|\|\|\| & $\mathrm{BEC}$ & 43.5 & \|\|\|\|\|\|\|\|\|\|\|\|$\|$ & FME4 & 40.4 & \|\|\|\|\|\|\|\|\|\|\|\| & FME5 70.9 & l. \\
\hline TAT5 & 25.1 & \|\|\|\|\|\|\|\| & BEY & 45.8\|\|\|\| & \|\|\|\|\|\|\|\|\|\|$\|$ & FME5 & 29.0\|\|\|\|\|\|\|\| & FME4 & 38.6 & \|\|\|\|\|\|\|\|\|\|$\|$ & FAS & 40.1 & \|\|\|\|\|\|\|\|\|\|$\|$ & FME6 $58.6 \|$ & \|\|\|\|\|\|\|\|\|\|\|\|\|\|\|\|\|\|$\|$ \\
\hline FME5 & 24.2 & \|\|\|\|\|\|\|\| & ATF3 & 45.7\|\|\|\| $\mid$ & $|\|\|\|\|\|\|\|\|\|\||$ & FME4 & 26.3\|\|\|\|\|\|\|\|$\|$ & BEY & 26.1 & \|\|\|\|\|\|\|\| & FME6 & 37.9 & \|\|\|\|\|\|\|\|\|\|\|\| & FME8 58.2 & \|\|\|\|\|\|\|\|\|\|\|\|\|\|\|\|\|\|$\|$ \\
\hline ATF2 & 24.2 & \|\|\|\|\|\|$\|$ & AGE & 34.8\|\|\|\| & \|\|\|\|\|\|$\|$ & BLS & 23.0\|\|\|\|\|\|$\|$ & BAC & 22.5 & \|\|\|\|\|\| & FME8 & 27.5 & \|\|\|\|\|\|\|\|$\|$ & FME4 57.9 & \|\|\|\|\|\|\|\|\|\|\|\|\|\|\|\|$\|$ \\
\hline TAT4 & 15.7 & \|\|\|\|$\|$ & NFM & 31.5\|\|\|\| & \|\|\|\|\|\|$\|$ & TIM & 22.8\|\|\|\|\|\|$\|$ & BLS & 20.3 & \|\|\|\|\|\| & TAT3 & 24.2 & \|\|\|\|\|\|$\|$ & PAV 57.8 & \|\|\|\|\|\|\|\|\|\|\|\|\|\|\|\|$\|$ \\
\hline NFM & 15.1 & \|\|\|\|$\|$ & FME3 & 31.0\|\|\|\| & \|\|\|\|\|\|$\|$ & GRA & 18.4\|\|\|\|$\|$ & FME3 & 19.5 & \|\|\|\|\|\| & ATF4 & 23.2 & \|\|\|\|\|\|$\|$ & AGE 53.2 & \|\|\|\|\|\|\|\|\|\|\|\|\|\|$\|$ \\
\hline FME6 & 10.7 & \|\|\|\| & BEC & 28.2\|\|\|\| & \|\|\|\|\|\| & FME6 & 14.8 ||||||| & ATF3 & 16.9 & \|\|\|\|$\|$ & PAV & 18.1 & \|\|\|\|$\|$ & FME3 38.6 & \|\|\|\|\|\|\|\|\|\|$\|$ \\
\hline EDU & 7.4 & IIII & ATF2 & 28.0\|\|\|\|$\|$ & & NFM & 14.2|||||||| & FME1 & 16.4 & .|l||||| & TAT1 & 15.2 & .1III) & GRA 35.6 & 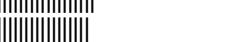 \\
\hline BAC & 7.3 & III & CITY & 25.7\|\|\|\| & & CITY & $13.7\|\mid\|\|\|$ & TAT5 & 15.8 & \|\|\|\|$\|$ & ATF1 & 14.1 & \|\|\|\| & FAS 34.2 & 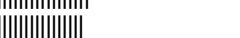 \\
\hline CITY & 5.7 & $\|$ & BAC & 22.2\|\|\|\| & & TAT6 & 12.7\|\|\|\| & GRA & 15.7 & \|\|\|\|$\|$ & AGE & 11.0 & $\||\|| \mid$ & TAT2 30.6 & \|\|\|\|\|\|\|\|$\|$ \\
\hline TAT6 & 5.5 & $\|$ & TAT3 & 22.2\|\|\|\| & & TAT4 & 11.4\|\|\|\| & ATF2 & 15.6 & \|\|\|\|$\|$ & TAT2 & 9.8 & \|\|$\|$ & FME1 22.1 & 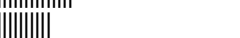 \\
\hline FME2 & 4.2 & $\|$ & TAT5 & 19.6\|\|\|\| & & FME2 & 10.7\|\|\|\| & TIM & 14.9 & \|\|\|\| & FME2 & 9.3 & III & FME2 21.9 & \|\|\|\|\|\| \\
\hline FME3 & 3.6 & " & TIM & 18.2\|\|\|\| & & ATF2 & 10.3\|\| & FME6 & 14.2 & \|\|\|\| & GRA & 8.0 & III & TAT6 20.4 & \|\|\|\|\|\| \\
\hline
\end{tabular}




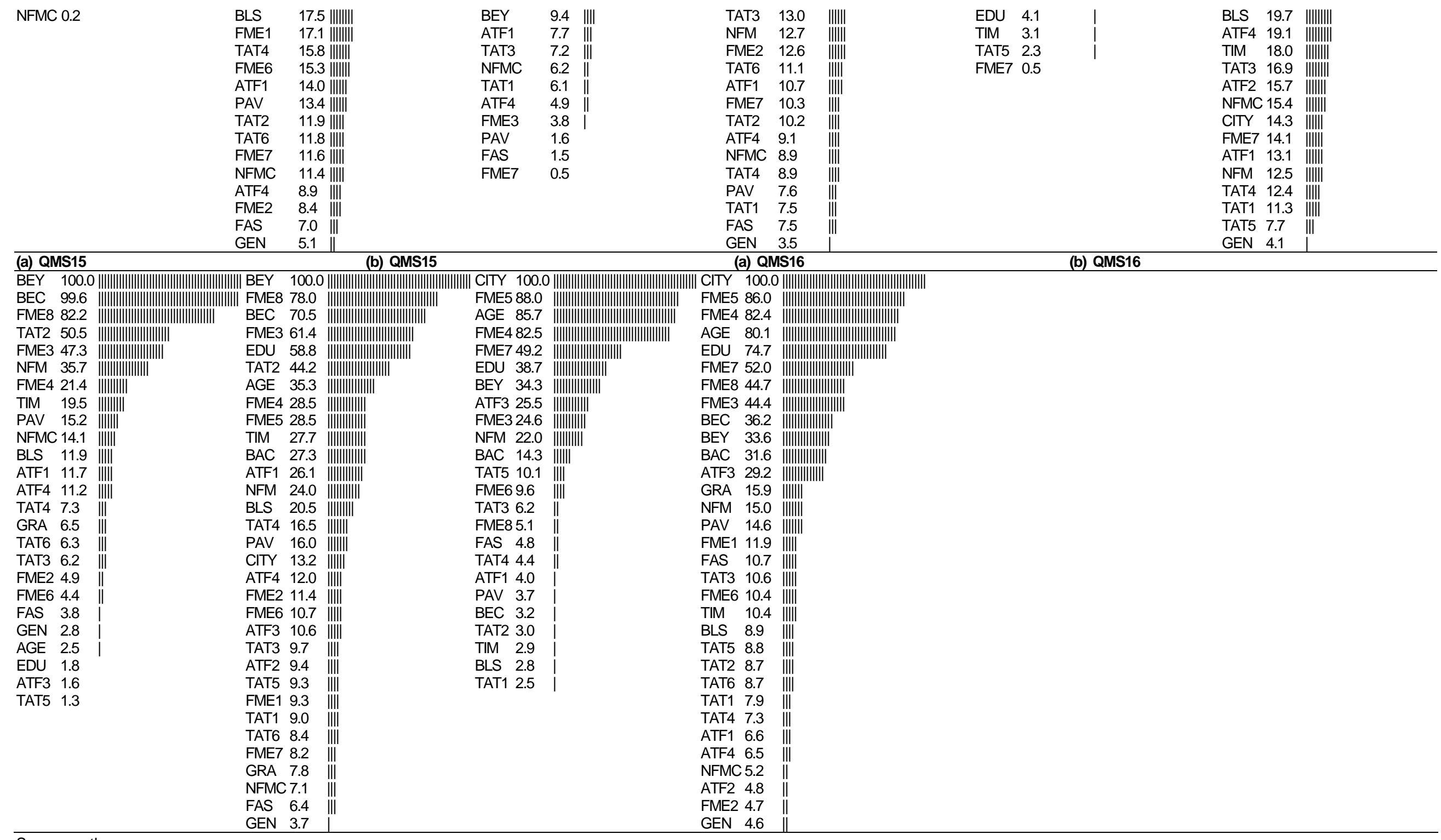

Source: authors 